\title{
MENGEMBANGKAN SEKOLAH DASAR BERBASIS MUTU DI INDONESIA UNTUK MENINGKATKAN KUALITAS LULUSAN
}

\author{
Slamet Widodo ${ }^{1}$, Yuni Yulianti ${ }^{2}$ \\ ${ }^{1}$ STKIP Al Hikmah, Jl. Kebonsari Elveka V Surabaya \\ Email: slamet.10050@gmail.com \\ ${ }^{2}$ MAIT Darul Fikri Sidoarjo, Jl. Putra Bangsa No. 1 Anggawangi, Sidoarjo \\ Email: yuniyulianti6392@gmail.com
}

\begin{abstract}
In welcoming AFTA (ASEAN Free Trade Area) and MEA (ASEAN Economic Community), Indonesian society's view on economy will be shifted to education. Schools will be excellent service product which will compete with each other. Particularly elementary schools will become major concern in creating skillful and competent graduates to face global challenges. Elementary schools will become the basic foundation for creating human resources who have qualified skills earlier based on the development of science and technology. Competent graduates of Elementary schools will be ready to compete at the global level, and vice versa. The way to produce competent graduates is by developing a quality-based elementary schools throughout Indonesia. Quality-based elementary school is an elementary school institution that prioritizes quality in producing competent graduates who are competent. The indicators of this quality-based elementary school consist of several criteria which are: 1) Focus on costumer, 2) total involvement, 3) Administering measurements, 4) Have high commitment, and 5) Performing sustainability improvement. Steps in building quality-based elementary schools are: 1) Organizing, 2) Planning, 3) Implementing, and 4) Monitoring. Hence, in order to embody a quality-based elementary school, it requires a good cooperation from all stakeholders and a strong commitment based on its indicators, steps and components.
\end{abstract}

Keywords: qualified elementary school, competent graduates, competency of global student.

\footnotetext{
ABSTRAK

Dalam menghadapi AFTA (ASEAN Free Trade Area) dan MEA (Masyarakat Ekonomi ASEAN) pandangan masyarakat Indonesia tentang ekonomi akan bergeser ke pendidikan. Sekolah akan menjadi ajang produk jasa yang bersaing antara sekolah satu dengan sekolah lainya. Khususnya pada sekolah dasar (SD) akan menjadi perhatian utama dalam menciptakan lulusan yang berkompeten (secara lebih dini siap) dalam menghadapi tantangan global. SD akan menjadi pondasi dasar untuk menciptakan sumber daya manusia (SDM) yang memiliki ilmu pengetahuan dan teknologi yang mumpuni dan sesuai dengan perkembangan zaman. Sehingga lulusan SD yang berkompeten akan siap bersaing di tingkat global, sebaliknya lulusan SD yang
} 
tidak berkompeten tidak siap untuk bersaing di tingkat global.Cara untuk menghasilkan lulusan yang berkompeten yaitu dengan mengembangkan SD berbasis mutu secara merata di seluruh Indonesia. SD berbasis mutu adalah lembaga SD yang mengutamakan mutu dalam menghasilkan lulusan yang berkompeten. Indikator atau kriteria SD bermutu terdiri dari:1)Fokus pada pelanggan,2) Keterlibatan total,3) Melakukan pengukuran,4) Komitmen, dan5) Melakukan perbaikan berkelanjutan. Langkah-langkah dalam membangun SD berbasis mutu, yaitu:1) Mengorganisasikan,2) Merencanakan,3) Mengimplementasikan,4) Memonitorg, dan 5. Perbaikan berkelanjutan. Jadi dapat disimpulkan bahwa mengembangkan SD bermutu memerlukan kerjasama semua pihak dan komitmen yang kuat dalam mewujudkannya sesuai dengan indikator sekolah bermutu, langkah-langkah dalam mewujudkan sekolah bermutu, dan perangkat sekolah bermutu.

Kata Kunci: sekolah dasar bermutu, lulusan berkompeten, kompetensi siswa global

\section{PENDAHULUAN}

Tantangan yang dihadapi bangsa Indonesia terhadap AFTA (ASEAN Free Trade Area) dan MEA (Masyarakat Ekonomi Asean) sudah nyata di depan mata. Tidak hanya masalah ekonomi dan persaingan kerja saja yang menjadi fokus utama, tetapi pendidikan yang berkualitas juga harus dipersiapkan. Hal tersebut disebabkan oleh pentingnya pendidikan dalam membentuk Sumber Daya Manusia (SDM) Indonesia yang berkualitas seperti pendapat yang dikemukakan oleh Barret dkk (2006) bahwa pendidikan merupakan usaha mengembangkan kualitas manusia. AFTA dan MEA harus dihadapi dengan kesadaran yang tinggi dan dijadikan sebagai bahan motivasi untuk meningkatkan kualitas pendidikan di Indonesia. Akan tetapi, jika dunia pendidikan lengah dalam menghadapi AFTA dan MEA bahkan menganggap remeh, maka berbagai dampak buruk seperti banyaknya sekolah asing yang lebih maju dari sekolah negeri, sekolah dalam negeri sepi peminat (input), hasil (outcome) lulusan sekolah negeri kurang diminati oleh masyarakat dan dunia kerja, siswa sekolah negeri kurang bisa bersaing dengan siswa sekolah asing dan sebagainya harus diterima.

SD adalah salah satu lembaga pendidikan yang harus ditingkatkan kualitasnya dalam rangka menyiapkan sumber daya manusia yang berkualitas. Upaya tersebut bertujuan agar siswa lulusan SD dalam negeri mampu bersaing dengan siswa lulusan sekolah asing. Walaupun secara rasional tidak mungkin siswa SD langsung bersaing di kancah global, tetapi dengan adanya SD negeri yang berkualitas maka akan membantu lulusannya agar mampu bersaing untuk memasuki jenjang Sekolah Menengah Pertama yang lebih baik. Selain itu, siswa dan lulusan SD dalam negeri akan mampu mengikuti kompetisi atau perlombaan di tingkat internasional.

SD yang tumbuh dan berkembang di Indonesia sangat banyak sekali, baik SD swasta maupun negeri. Setiap desa di Indonesia pasti memiliki satu SD Negeri, bahkan pembangunan SD terus tumbuh pesat sampai satu desa memiliki lebih dari satu SD. Berdasarkan data dari UNESCO tentang Teachers and Educational quality: Monitoring Global Need for 2015 menunjukkan pertumbuhan jumlah guru dan sekolah yang sangat signifikan di Indonesia. Data pada tahun 1971 
sampai dengan tahun 2004 menunjukkan bahwa jumlah guru di Indonesia mencapai 2,6 juta. Demikian juga dengan jumlah sekolah yang tentu sangat banyak. Akan tetapi, walaupun dari kuantitas tentu pertumbuhan pembangunan SD di Indonesia terus tumbuh sangat signifikan, kualitas sekolah dan gurunya masih belum diperhatikan secara maksimal.

Salah satu kurang maksimalnya kualitas SD di Indonesia dapat diketahui dari kurang berkualitasnya produk yang diluluskan. Sedangkan, sekolah yang berkualitas biasanya akan menghasilkan siswa atau lulusan yang mampu bersaing di tingkat internasional, misal dalam mengikuti lomba dan olimpiade. Selain itu, kemampuan mereka dalam menguasai ilmu pengetahuan seperti Matematika dan Ilmu Pengetahuan Alam (MIPA) dan literasi tidak terlalu tertinggal dengan siswa lain di dunia. Akan tetapi hal tersebut masih menjadi tugas besar bagi bangsa Indonesia untuk diwujudkan. Data menunjukkan bahwa siswa pada tingkat sekolah dasar dan menengah di Indonesia memiliki kemampuan literasi membaca pada tahun 2006 berada pada peringkat ke 48 dari 56 negara (OECD, 2007). Kemampuan siswa Indonesia dalam menguasai matematika menunjukkan posisi pada peringkat ke 50 dari total 57 seluruh negara (OECD, 2007). Sedangkan, kemampuan siswa Indonesia dalam menguasai sains berada pada posisi peringkat ke-50 dari total 57 negara (OECD, 2007). Selain data tersebut, data dariProgress in International Reading Literacy Study (PIRLS) juga menunjukkan bahwa pada tahun 2006 dalam kemampuan membacasiswa kelas IV sekolah dasar Indonesia berada di posisi peringkat 41 dari jumlah 45 negara di seluruh dunia. Data tersebut diperoleh dari koordinasiThe International Association for the Evaluation of Educational Achievement (IEA) yang telah diikuti oleh berbagai negara di dunia, baik negara maju maupun negara berkembang dalam mengetahui dan mengidentifikasi kemampuan siswa di berbagai negara di dunia (OECD, 2006). Selaian itu, hasil PISA (Programme for International Student Assessment) pada kompetensi sain dan literasi untuk usia usia 15 tahun menunjukkan hasil yang rendah yaitu lebih rendah di bawah rata-rata Negara lainnya, (OECD, 2019).

Oleh karena itu, kualitas pendidikan di Indonesia khususnya pada tingkat SD harus ditingkatkan. Menurut Barret dkk (2006) kualitas pendidikan merupakan garis utama, garis utama didefinisikan sebagai esensi utama tentang tujuan dan nilai dari aktivitas manusia dalam pendidikan. Tujuan peningkatan kualitas pendidikan, khususnya tingkat SD adalah untuk meningkatkan kemampuan lulusan, karena lulusan yang berkualitas merupakan produk sekolah yang berkualitas. Untuk mewujudkan kualitas lulusan SD di Indonesia membutuhkan kerjasama semua pihak. Upaya tersebut membutuhkan komitmen antara masyarakat, warga sekolah, dan pengambil kebijakan. Lembaga SD memiliki peran yang sangat penting, karena SD merupakan lembaga yang bertanggungjawab dalam membentuk dan mewujudkan siswa yang berkualitas secara langsung. Lembaga SD memiliki tugas secara langsung mendidik dan mengajarkan siswa tentang berbagai disiplin ilmu. Hal tersebut sesuai dengan Propet dkk (dalam Barret dkk, 2006) bahwa sekolah adalah tempat dimana siswa menerima sikap dan nilai budaya. Lembaga SD harus mampu mengelola segala 
potensi yang dimilikinya untuk mewujudkan sekolah dan lulusan yang berkualitas. Lembaga SD harus menyiapkan sarana, sistem pembelajaran, kebutuhan masyarakat, dan menghadapi tantangan global termasuk AFTA dan MEA dengan baik.

Ilmu pengetahuan dan teknologi yang terus berkembang menjadi sebab masyarakat memilih SD yang berkualitas. Apalagi dalam AFTA dan MEA yang memungkinkan siapa saja dapat mendirikan sekolah, termasuk warga asing. Lembaga SD dalam negeri harus menyadari untuk meningkatkan kualitas sekolahnya dalam menghadapi tuntutan global tersebut. Kelemahan dalam meningkatkan kualitas SD harus diminimalisir sedini mungkin. Tujuannya adalah untuk menghindari sepinya peminat SD Indonesia. Jika SD dalam negeri enggan untuk meningkatkan kualitasny a, maka masyarakat pasti memilih SD yang berkualitas walaupun SD tersebut didirikan oleh warga asing. Tentunya sebagai bangsa Indonesia akan merugi, karena uang yang seharusnya masuk ke lembaga SD dalam negeri akhirnya masuk ke sekolah-sekolah asing.

Dalam AFTA dan MEA pandangan tentang ekonomi akan bergeser ke pendidikan. Sekolah akan menjadi ajang produk jasa yang bersaing antara sekolah satu dengan sekolah lainya. Walaupun mungkin ada aturan pemerintah yang melarang berdirinya sekolah asing di Indonesia, tetapi seiring arus global yang semakin nyata dan kuat maka aturan tersebut akan direvisi sesuai dengan keadaan di lapangan. Hal tersebut sudah terbukti dari mulai banyaknya kampus-kampus luar negeri yang membuka cabang di Indonesia. Akibatnya, kampus dalam negeri akan bersaing meningkatkan kualitasnya dengan kampus yang berasal dari luar negeri. Begitu pula pada tingkat SD, pasti akan masuk lembaga SD milik asing yang akan berdiri di Indonesia untuk bersaing dengan lembaga SD dalam negeri.

Oleh karena itu, untuk mewujudkan lembaga SD dalam negeri yang berkualitas dan mampu bersaing dengan lembaga SD asing perlu ada usaha yang sungguh-sungguh. Salah satu caranya adalah mengembangkan SD berbasis mutu. Mengapa yang ditingkatkan harus mutu? Apakah mutu akan menciptakan kualitas lulusan SD yang bagus?. Jawabanya adalah bahwa mutu akan meningkatkan kualitas lulusan siswa SD, karena mutu akan melihat dari banyak sudut pandang, antara lain yaitu: masyarakat, guru, administrator, staf sekolah, komite sekolah, fisik gedung, sarana prasarana, orang tua, sistem, komitmen, dan perbaikan yang berkelanjutan. Hal tersebut sesuai dengan pendapat Arcaro (2007) yang menyatakan bahwa karakteristik sekolah bermutu dapat diketahui dari lima pilar utama, yakni: fokus pada kostumer, keterlibatan total, pengukuran, komitmen, dan perbaikan berkelanjutan.

\section{METODE}

Penelitian ini merupakan jenis penilitian kajian pustaka, dengan melihat permasalahan yang dihadapi oleh sekolah dan menyelesaikannya dengan mancari sumber-sumber referensi yang relevan. Sobjek penelitian ini adalah siswa SD dengan tidak memperhatikan populasi dan sampel, sedangkan objek penelitiannya adalah SD-SD di Indonesia yang mutu sekolah dan lulusannya masih rendah, 
baik secara hasil akreditasi maupun real bagi pihak-pihak yang berkepentingan. Metode pengumpulan data yang digunakan adalah membaca dana analisis berbagai sumber referensi bacaaan baik cetak mauapun elektronik. Instrumen penelitian yang digunakan adalah lembar analisis bahan bacaan. Teknik analisis data yang digunakan adalah triangulasi dengan mereduksi data supaya mendapat klasifikasi data yang tepat

\section{HASIL DAN PEMBAHASAN}

\section{Definisi SD Berbasis Mutu}

Dalam bahasa inggris mutu diartikan sebagai kualitas. Pada dasarnya makna dari kata kualitas sama dengan kata mutu, hanya saja beda istilah, karena dipengaruhi oleh perbedaan penggunaan pada suatu negara. Dari segi arti, mutu menurut kamus besar bahasa Indonesia merupakan ukuran baik buruk suatu benda. Menurut Arcaro (2007) menjelaskan bahwa mutu adalah sebuah proses terstruktur untuk memperbaiki keluaran yang dihasilkan. Jika dihubungkan dengan lembaga SD, SD bermutu merupakan proses terstruktur yang dilakukan lembaga sekolah dalam rangka mewujudkan keluaran atau hasil lulusan yang baik. SD bermutu merupakan standar yang ditetapkan untuk setiap pengorganisasian kerja pada keseluruhan sistem kerja sekolah. Di dalam lembaga SD semua bagian kerja yang telah diorganisasikan memiliki standar masing-masing. Standar tersebut mengarah pada satu tujuan besar, yaitu untuk menghasilkan lulusan yang bermutu. Di Indonesia, untuk mengetahui siswa yang bermutu diketahui nilai di rapor. Rapor berkaitan dengan hasil belajar yang dilakukan oleh siswa dalam mengikuti pembelajaran di sekolah. Oleh karena itu, siswa yang memiliki rapor yang baik pasti sekolah memiliki standar mutu pada setiap bagian sistem kerja, seperti: administrasi, fasilitas, kurikulum, guru yang berkualitas, dan lain sebagainya. Akan tetapi, kenyataanya untuk menghasilkan rapor yang baik semua dibebankan pada guru. Gurumenjadi kunci utama dalam menghasilkan lulusan yang bermutu. Padahal tidak hanya guru saja yang menjadi faktor dalam membangun sekolah bermutu, tetapi juga semua bagian dari sistem yang ada di sekolah. Guru hanya bagian dari keseluruhan sistem kerja dalam menghasilkan lulusanyang bermutu. Dalam membangun SD yang bermutu membutuhkan kerjasama semua pihak, baik warga sekolah ataupun masyarakat. Semua sistem kerja disekolah ditentukan standar mutu dan dilakukan dengan penuh tanggungjawab oleh semua warga sekolah, yakni: guru, kepala sekolah, pegawai, dan siswa. Begitu pula masyarakat mendukung sistem kerja yang telah ditetapkan standar mutu oleh sekolah. Orang tua, pejabat, pemuka adat, pebisnis dan semua unsur masyarakat mendukung sistem kerja sekolah. Setiap masyarakat memberikan dukungannya sesuai dengan peran yang dimilikinya, memberikan berbagai sumber daya dalam rangka menghadapi tantangan sekarang dan masa depan. Hal tersebut didukung dengan pendapat Arcaro (2007) yang menyatakan bahwa mutu menciptakan lingkungan bagi pendidik, orang tua, pejabat pemerintah, wakil-wakil masyarakat, dan pemuka bisnis untuk bekerja sama guna memberikan kepada para siswa sumber-sumber daya yang dibutuhkan untuk memenuhi tantangan masyarakat, bisnis, akademik di masa sekarang dan yang akan datang. Sekolah 
dan masyarakat bekerja sama dan mengevaluasinya secara berkelanjutan sesuai temuan-temuan selama sistem sekolah berjalan. Perlu ditekankan bahwa sumber daya tersebut tidak diartikan sebagai uang saja, melainkan berupa dukungan yang mengarah pada tercapainya tujuan dari setiap organisasi sistem kerja sekolah. Contohnya sekolah sudah menetapkan batasan jumlah jam belajar semua siswa ketika di rumah, maka sebagai orang tua dari siswa ikut mendorong dengan cara selalu mengingatkan atau bahkan mengawasi anaknya sesuai dengan aturan sekolah, supaya program yang telah ditetapkan di sekolah berhasil. Karena ada sebagian masyarakat yang beranggapan bahwa mendukung sekolah berarti menyumbang uang ke sekolah. Padahal tidak demikian, lulusan yang bermutu adalah keberhasilan semua system sekolah dan juga masyarakat. Karena, tidak mungkin sekolah saja yang memiliki kewajiban mewujudkan lulusan bermutu, tetapi juga masyarakat ikut serta dalam mewujudkan. Hal ini sesuai dengan lingkungan siswa, yang tidak hanya dihabiskan di lingkungan sekolah saja, tetapi di lingkungan masyarakat siswa lebih banyak beraktivitas. Untuk mempermudah dalam membangun SD bermutu maka perlu diterapkan prinsip-prinsip mutu. Tujuan prinsip tersebut adalah untuk menentukan arah kerja lembaga sekolah yang maksimal dan efektif. Deming (dalam Arcaro, 2007) menentukan 14 prinsip dalam mewujudkan sekolah bermutu, yang kemudian dinamakan dengan"Hakikat Mutu dalam Pendidikan”. Prinsip-prinsip tersebut yaitu: 1) menciptakan konsistensi tujuan. Tujuan sekolah diarahkan untuk menciptakan layanan sekolah dan lulusan yang bermutu menuju sekolah yang berkelas dunia. 2) mengadopsi filosofi mutu total. Mutu total merupakan hasil lulusan yang sesuai dengan kebutuhan dan tuntutan global. 3) mengurangi kebutuhan pengujian, tetapi lebih mengutamakan lingkungan belajar siswa yang mengarah kinerja siswa yang bermutu. 4) meminimalkan biaya total pendidikan dengan cara menilai bisnis sekolah dengan cara baru. 5) memperbaiki mutu dan produktivitas serta mengurangi biaya. 6) belajar sepanjang hayat. Belajar secara terus-menerus sampai terciptanya sistem sekolah yang bermutu. 7) menjalankan kepemimpinan dalam pendidikan yang efektif dan efisien. 8) mengeliminasi rasa takut. Selama setiap bagian dari sekolah sesuai dengan tujuan mutu maka bebas berpendapat dan melakukan segala hal. 9) mengeliminasi hambatan keberhasilan. 10) menciptakan budaya mutu. 11) perbaikan proses. 12) membantu siswa untuk berhasil. 13) komitmen. 14) tanggung jawab. Dari prinsip mutu tersebut dapat diturunkan dalam aspek kinerja sekolah, seperti tabel berikut ini.

Tabel 3.1. Prinsip dan Aspek Mutu dalam Mengembangkan SD

\begin{tabular}{lll}
\hline No. & \multicolumn{1}{c}{ Prinsip } & \multicolumn{1}{c}{ Aspek } \\
\hline 1 & Konsistensi tujuan & Fokus \\
\hline 2 & Mutu total & Kinerja yang menyeluruh \\
\hline 3 & Belajar yang bermutu & Proses menghasilkan output-outcome \\
\hline 4 & Efiseinsi anggaran & Pengelolaan anggaran \\
\hline
\end{tabular}




\begin{tabular}{lll}
\hline 5 & Perbaikan berkelanjutan & Peningkatan \\
\hline 6 & Belajar terus-menerus & Kemauan mengikuti perubahan \\
\hline 7 & Kepemimpinan yang profesional & Pelaksanaan organisasi \\
\hline 8 & Mengurangi rasa takut & Mental \\
\hline 9 & Mengurangi hambatan & Kemampuan analisis hambatan \\
\hline 10 & Menciptakan budaya mutu & Kebiasaan \\
\hline 11 & Memperbaiki proses & Prosedur kinerja \\
\hline 12 & Membantu semua siswa sampai berhasil & Fokus kualitas lulusan \\
\hline 13 & Komitmen & Sikap kerja \\
\hline 14 & Tanggungjawab & Sikap kerja \\
\hline
\end{tabular}

\section{Menentukan Kriteria SD Bermutu}

Untuk dapat menentukan sekolah bermutu, terlebih dahulu harus dipahami kriteria sekolah bermutu. Sekolah dapat dikatakan bermutu jika sesuai dengan kriteria yang telah ditetapkan. Ada banyak kriteria yang diterapkan menuju sekolah bermutu. Masing-masing sekolah menerapkan kebijakan mutu sesuai dengan kebutuhan dan tantangan. Menurut Beeby (dalam Barret dkk, 2006) konsep mutu pendidikan dibedakan menjadi tiga tingkatan, yaitu: pertama, mutu ruang kelas, yang fokus utamanya adalah penerimaan dari pengukuran pengetahuan dan keterampilan pembelajaran, mengukur kebiasaan, sikap, termasuk sikap tanggung jawab dan cinta negara. Kedua, adalah mutu pendidikan harus melayani tujuan ekonomi dalam hubunganya dengan siswa dan kehidupan. Ketiga, mutu adalah penilaian kualitas oleh masyarakat luas. Beeby berpendapat bahwa sekolah bisa dikatakan bermutu jika ruang kelas bermutu, tujuan sekolah bermutu adalah untuk memenuhi tuntutan ekonomi, dan sekolah bermutu memperhatikan penilaian masyarakat. Sedangkan Menurut Osaki (2000) bahwa unsur kualitas dalam sekolah dibedakan menjadi 4, yaitu: pertama, dukungan lingkungan luar, berisi tentang sistem pendidikan, orang tua dan masyarakat, pebelajar, sumber dan fasilitas. Kedua, keinginan karakteristik internal, berisi tentang efektifitas kepemimpinan, kemampuan dan efektifitas guru, cara kerja yang terbuka, objektiv dalam visi dan misi, dan maksimalnya kegiatan di sekolah baik oleh staf ataupun siswa. Ketiga, penekanan pada efektifitas kegiatan belajar mengajar, berisi tentang fokus pada kurikulum, penggunaan waktu yang maksimal dalam pembelajaran, menggunakan berbagai macam variasi kegiatan mengajar, ketertiban memonitoring siswa. Keempat, iklim sekolah yang menyenangkan, berisi tentang kedisiplinan, memberikan penghargaan terhadap pekerjaan yang baik, sikap yang positif dari guru, dan sikap kerjasama antar siswa. Osaki berpendapat bahwa sekolah dinyatakan bermutu jika mendapat dukungan masyarakat, karakteristik internal sekolah yang bermutu, efetivitas kegiatan belajar mengajar, dan iklim sekolah yang menyenangkan. Pendapat lain yang lebih lengkap yakni menurut 
Arcaro (2007) karakteristik sekolah bermutu dibangun atas dasar 5 pilar utama yang kemudian dinamakan "karakteristik sekolah bermutu terpadu". Pilar-pilar tersebut yakni: 1) Fokus pada kostumer. Kostumer yang dimaksud adalah orang yang akan memetik manfaat secara langsung dari adanya sekolah yang bermutu. Secara khusus kostumer ini adalah siswa dan orang tua siswa kemudian dapat dirasakan pula oleh masyarakat luas. Salah satu cara yang dapat dilakukan oleh sekolah dalam membangun sekolah bermutu adalah sekolah secara rutin melakukan pertemuan dengan orang tua siswa di rumahnya untuk membahas prestasi belajar siswa. Jenis kostumer ada 2 yakni: kostumer internal dan kostumer eksternal. Bagian dari kostumer internal antara lain: orang tua, siswa, guru, administrator, staf, dan dewan sekolah berada pada sistem pendidikan. Sedangkan bagian dari kostumer eksternal antara lain: masyarakat, perusahaan, keluarga, militer, dan perguruan tinggi yang berada di luar organisasi, namun memanfaatkan output proses pendidikan.

2) Keterlibatan total, artinya semua orang dengan berbagai peran masing-masing ikut berpartisipasi dalam membangun sekolah bermutu. Sekolah bermutu bukan tanggung jawab sekolah saja, melainkan tanggung jawab semua pihak sesuai dengan perannya. Sekolah membuat sistem bermutu dengan tujuan menghasilkan siswa yang bermutu, sedangkan orang tua dan masyarakat mendukung sistem dari sekolah tersebut ketika siswa berada di rumah dan masyarakat contohnya jika para siswa di luar sekolah melakukan perbuatan yang melanggar sistem sekolah maka orang tua dan masyarakat berkewajiban untuk menegur atau mengingatkan. Untuk mewujudkan keterlibatan total tersebut membutuhkan koordinasi, kerjasama, dan kesepakatan dengan semua pihak, dapat dilakukan dengan melakukan pertemuan secara langsung anatara pihak sekolah dengan orang tua dan masyarakat.

3) Melakukan pengukuran, artinya melakukan pengukuran dari setiap sistem sekolah. Setiap bagian dari sitem sekolah memiliki pengukuran sendiri-sendiri sesuai dengan yang telah ditetapkan sekolah. Contohnya nilai hasil belajar siswa digunakan untuk mengukur keberhasilan belajar di kelas. Laporan keuangan sekolah dilakukan secara transparan dan bertanggung jawab ke semua pihak untuk mengukur efisiensi penggunaan biaya sekolah dan jenis-jenis pengukuran yang lainya yang dapat digunakan sekolah.

4) Komitmen. Dalam mewujudkan sekolah bermutu harus dilakukan dengan komitmen yang tinggi oleh semua pihak. Terutama sekolah harus memiliki komitmen pada mutu sekolah. Menurut Arcaro (2007:42) menyatakan bahwa mutu merupakan perubahan budaya yang mengubah cara kerjanya. Untuk mendukung perubahan dalam sistem sekolah, maka sekolah harus memfasilitasi dan mendorong setiap bagian dari sistem sekolah. Tujuannya adalah untuk memberikan dukungan kepada semua orang yang terlibat dalam mewujudkan sekolah bermutu.

5) Melakukan perbaikan berkelanjutan. Seiring dengan berjalan proses menuju sekolah bermutu, pasti ditemukan berbagai kendala dan masalah. Berbagai kendala dan masalah harus diselesaikan dengan cara yang tepat, kemudian dilakukan perbaikan pada bagian mana saja yang 
masih belum tepat. Pasti pada setiap bagian sistem sekolah dalam proses menuju kesempurnaan membutuhkan perbaikan berkelanjutan. Sehingga perbaikan sedikit demi sedikit pada setiap prosesnya akan menciptakan kesempurnaan sistem sekolah yang bermutu.

Jadi dapat disimpulkan bahwa kriteria sekolah dasar bermutu adalah 1) fokus pada kostumer, baik kostumer internal maupun kostumer eksternal, 2) melibatkan semua orang yang memiliki kepentingan dengan sekolah dasar sesuai dengan perannya masing-masing, 3) melakukan pengukuran terhadap semua sistem yang ada di dalam sekolah dasar, 4) memiliki komitmen yang tinggi dalam mewujudkan sekolah bermutu, 5) melakukan perbaikan secara berkelanjutan untuk menyempurnakan sistem yang sudah dibuat oleh sekolah dasar. Berikut ini kriteria SD berbasis mutu.

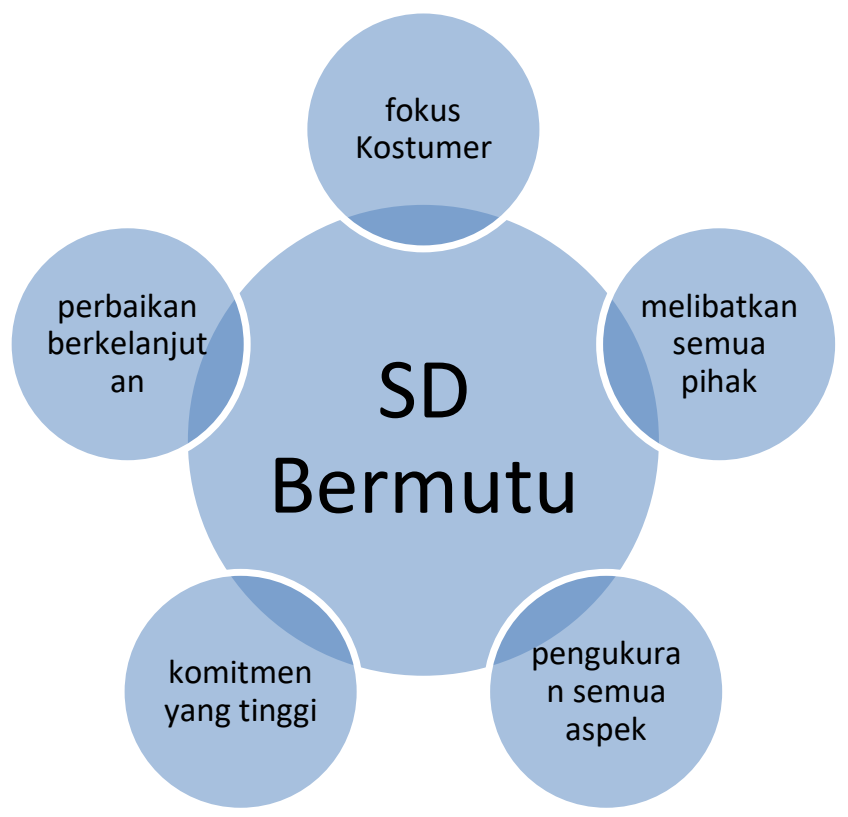

Bagan 3.1. Kriteria SD Bermutu

\section{Langkah-Langkah Dalam Mengembangkan SD Berbasis Mutu}

Untuk mewujudkan SD berbasis mutu, diperlukan langkah yang tepat supaya tujuan yang ingin dicapai sekolah dasardapat diwujudkan dengan baik. Langkah-langkah tersebut dibagi menjadi menjadi lima, yaitu: 1. Mengorganisasikan, 2. Merencanakan, 3. Mengimplementasikan, 4. Memonitoring, dan 5. Perbaikan berkelanjutan. Setiap tahap tersebut akan dijelaskan secara terperinci berikut ini. 


\section{pengorganisasian sumber daya}

perncanaan yang terorganisir

implementasi berdasarkan rencana dan dikontrol

memonitoring dan evaluasi hasil

Melakukan perbaikan berkelanjutan

Bagan 3.2. Prosedur Pengembangan SD Bermutu

\section{UCAPAN TERIMA KASIH (Optional)}

Langkah yang pertama, mengorganisasikan adalah mengelompokkan sumber daya manusia di sekolah dasaryang sesuai dengan kompetensinya. Dalam kegiatan mengorganisasikan dibentuk komite penjamin mutu bertujuan untuk menjamin keberlangsungan mutu yang ada di sekolah dasar. Menurut Arcaro (2007) dalam fase ini komite penjamin mutu menentukan adanya kebutuhan pembentukan satuan tugas dan melacak jumlah satuan tugas yang dibentuk dan orang yang ditugaskan pada masingmasing tim.komite penjamin mutu dibentuk dengan beban tugas selain tugas secara struktural dan fungsional, seperti kepala sekolah, wakil kepala sekolah, ketua komite sekolah, kepala Tata Usaha, kepala laboratorium, kepala perpustakaan, dan lainnya sesuai dengan yang ada di sekolah dasar.

Jika dalam sekolah sudah dibentuk komite penjamin mutu, maka akan mempermudah sekolah dasar dalam melaksanakan mutu, karena komite penjamin mutu akan membagi tugas dan mengawasi keberlangsungan sekolah dalam melaksanakan sekolah dasar berbasis mutu. Siapapun pihak dapat memberikan kritik ataupun saran kepada komite penjamin mutu, ketika ditemukan ketidaksesuaian pelaksanaan kebijakan mutu yang telah diselenggarakan oleh sekolah dasar. Selanjutnya, komite penjamin mutuakan memecahkan masalah sesuai dengan kritik atau saran dengan cara mengevaluasi program kebijakan mutu. Walaupun kepala sekolah adalah orang yang memegang kebijakan sekolah dasar, akan tetapi orang yang berhak bertanggungjawab terhadap 
kebijakan mutu sekolah dasar adalah komite penjamin mutu, karena komite penjamin mutu merupakan orang yang mengurusi pelaksanaan kebijakan mutu.

Langkah yang kedua, merencanakan adalah menyusun segala kegiatan dan kebijakan yang ada di sekolah dasar dalam mewujudkan sekolah dasar berbasis mutu. Menurut Muhaimin dkk (2012) menyatakan bahwa dalam rangka mewujudkan tujuan sekolah perlu disusun rencana strategis dan cara mencapai tujuan tersebut. Sekolah dapat menyusun segala hal yang diperlukan baik berupa program kegiatan ataupun kebijakan dalam rangka mewujudkan sekolah dasar berbasis mutu.

Rencana sekolah disusun dengan mempertimbangkan berbagai hal, antara lain kebutuhan masyarakat, peluang, ancaman, kekuatan, kelemahan, kelebihan dan kekurangan sekolah. Rencana sekolah dapat disusun dengan cara melakukan koordinasi antara semua warga sekolah, masyarakat, dan orang tua. Koordinasi tersebut dapat dilakukan dalam bentuk rapat atau pertemuan secara terjadwal oleh sekolah dasar. Rapat tersebut dibahas tentang hal-hal yang diperlukan dalam mewujudkan sekolah bermutu. sekolah dasar memberikan pengarahan kepada semua pihak tentang pentingnya membangun sekolah dasar berbasis mutu. Bertujuan melalui pemahaman yang diberikan sekolah dasar kepada semua pihak, maka semua pihak tersebut akan dapat membantu dan berpartisipasi langsung kepada sekolah dasar. Sehingga semua pihak merasa memiliki tanggungjawab terhadap keberhasilan sekolah dasar berbasis mutu.

Langkah yang ketiga adalah mengimplementasikan mutu dalam kurikulum,kelas, proses pembelajaran, kedisiplinan, pembiayaan, sarana dan prasarana dan keterlibatan orang tua. Semua komponen tersebut harus ditetapkan standar mutu oleh sekolah dasar. Kurikulum harus dibuat beradasarkan kebutuhan lingkungan sekitar dan kurikulum dibuat tanpa menyimpang dari kurikulum pendidikan nasional. Kurikulum tersebut dibuat dengan menonjolkan keterampilan dan kemampuan sesuai kebutuhan dan tantangan zaman ke depan. Hal itu sejalan dengan pendapat Idi (2014) kurikulum dan proses pendidikan seharusnya dapat diorientasikan pada kebutuhan dunia kerja, sehingga pengetahuan teoretik di sekolah dapat diaplikasikan dengan baik dalam dunia kerja. sekolah dasar harus pandai mengetahui situasi dan kondisi lingkungan sekolah berada. Jika masyarakat sekitar merupakan lingkungan pertanian, maka kurikulum sekolah dasar juga harus mengarah pada keterampilan dan kemampuan tentang bertani. Tujuan penyesuaian tersebut adalah memberikan keterampilan dan kemampuan dasar bagi siswa tentang tata cara mengelola potensi lingkungan sekitar.

Di dalam kelas juga harus ditentukan standar mutu. sekolah dasar harus menentukan mutu kelas tentang administrasi, sarana dan prasarana, denah tempat duduk, kebersihan, dan kelengkapan sumber belajar. Jika sudah ditentukan standar mutu kelasnya, maka sekolah akan mudah memantau kegiatan pembelajaran yang dilaksanakan oleh kelas tersebut. Selain itu, sistem pembelajaran di sekolah dasar juga harus ditentukan standar mutu. sekolah dasar harus merancang sebaik mungkin 
tentang kelengkapan buku sekolah, perencanaan pembelajaran, strategi yang harus dikuasai oleh guru, dan sumber belajar yang memadai.

Begitupula untuk proses pembelajaran, kedisiplinan, pembiayaan, sarana dan prasarana dan keterlibatan orang tua, juga harus ditentukan standar mutu. sekolah dasar membuat langkah-langkah strategis untuk menentukan mutu yang ideal bagi setiap sistem tersebut. Ciri khas proses pembelajaran di sekolah ditentukan untuk menciptakan lulusan yang berkualitas. Kedisiplinan dalam menjalankan aturan di sekolah harus ditegakkan secara adil. sekolah dasar harus membuat rincian secara detail tentang pendanaan di sekolah, dan kemudian dilaporkan secara transparan kepada semua pihak. Tujuan diperinci tersebut adalah agar semua pihak merasa puas tentang laporan keuangan yang ada di sekolah. Jika suatu saat ada hal yang yang membutuhkan pembiayan di sekolah, maka semua pihak yang merasa memiliki kepentingan di sekolah akan senantiasa memberikan bantuan. Segala sarana dan prasarana sedikit demi sedikit sekolah harus mengusahakan untuk melengkapi kekurangannya. Sekolah harus berusaha melengkapi sarana dan prasarana, supaya pembelajaran di sekolah dapat berjalan dengan lancar. Selain itu juga, sekolah harus membangun sistem kerjasama yang baik dengan orang tua siswa. Tujuannya adalah untuk mewujudkan rasa tanggungjawab antara sekolah dan orang tua sesuai dengan perannya masing-masing. Jika ada program dari sekolah yang membutuhkan bantuan orang tua, maka orang tua akan merasa bertanggungjawab terhadap program sekolah tersebut. Karena tidak mungkin sekolah akan membentuk lulusan yang berkualitas jika orang tua tidak mendukungnya. Waktu yang dihabiskan para siswa juga tidak sepenuhnya dilakukan di sekolah, bahkan lebih banyak dihabiskan di lingkungan keluarga dan masyarakat. Oleh karena itu, maka sangat penting untuk membangun kerjasama yang baik antara sekolah dan orang tua.

Langkah yang keempat adalah melakukan monitoring terhadap standar mutu yang diterapkan di sekolah. Monitoring adalah melakukan pelaporan terhadap kinerja yang telah dilakukan, dan jika ada kekurangan selama dijalankan kinerja maka dilakukan evaluasi. Monitoring menjadi bahan untuk memantau pelaksanaan standar mutu yang diterapkan sekolah. Untuk mewujudkan monitoring yang baik, sekolah harus menetapkan bagian-bagian pada setiap standar mutu secara detail. Monitoring dilakukan secara terjadwal dengan membuat kesepakatan oleh warga sekolah. Setelah dilakukan monitoring maka sekolah dapat menentukan apakah standar mutu yang diterapkan dapat dilanjutkan atau tidak, ada yang diperbaiki atau tidak. Selanjutnya, sesuai dengan hasil monitoring tersebut sekolah dapat melakukan perbaikan.

Tahap kelima untuk mewujudkan sekolah dasar berbasis mutu adalah melakukan perbaikan berkelanjutan. Standar mutu yang telah diterapkan sekolah membutuhkan kesempurnaan. Untuk mencapai kesempurnaan standar mutu tersebut maka dibutuhkan perbaikan berkelanjutan. Melalui monitoring, sekolah dapat mengetahui bagian-bagian standar mutu yang membutuhkan perbaikan. Perbaikan tersebut dilakukan setiap selesai monitoring secara berkelanjutan. Sehingga dengan 
adanya perbaikan secara berkelanjutan maka kekurangan standar mutu yang diterapkan sedikit demi sedikit akan menjadi standar mutu yang sempurna.

\section{Penyelesaian Masalah}

Dalam mewujudkan sekolah dasar berbasis mutu pasti ditemukan permasalahan. masalah tersebut dapat terjadi pada awal perintisan atau di tengah perjalanan. Oleh karena itu, sangat diperlukan kemampuan dalam menyelesaikan masalah-masalah tersebut, agar masalah yag terjadi dapat diselesaikan dengan baik dan dampaknya tidak menyebar ke bagian-bagian yang lainya. Menurut Santrok (2010), Terdapat 4 langkah yang efektif dalam menyelesaikan masalahsecara prosedural, yakni;1) memahami masalah, 2) menyusun strategi pemecahan masalah yang baik, 3) mengeksplorasi solusi, dan 4) memikirkan kembali masalah dan solusi.

Hal yang pertama dilakukan adalah memahami masalah yang sedang terjadi di sekolah. Sekolah harus memastikan bahwa yang sedang dihadapi merupakan benar-benar masalah. Sejalan dengan hal itu, Mayer (dalam Santrock, 2010) yang menyatakan bahwa sebelum masalah dapat dipecahkan maka yang dilakukan adalah harus mengenalinya terlebih dahulu. Untuk mengetahui bahwa yang dihadapi merupakan masalah atau bukan dapat diketahui dengan memperhatikan apakah masalah tersebut benarbenar membutuhkan penyelesaian. Masalah dapat timbul kapan saja tanpa memperhatikan penerimanya. Hal yang terpenting adalah memahaminya dan bersikap tenang.

Langkah yang kedua adalah menyusun strategi pemecahan masalah yang baik. Menyusun strategi pemecahan masalah merupakan kegiatan merencanakan, memikirkan, dan mengurutkan langkahlangkah yang harus ditempuh sekolah dalam menyelesaikan masalah. Strategi disusun dengan melihat dan menyesuikan permasalahan yang dihadapi. Dalam menentukan strategi diperhitungkan dan dipertimbangkan kemungkinan-kemungkinan yang akan terjadi. Faktor-faktor yang menjadi pendorong dan penghalang dianalisis, supaya dalam penyelesaian dapat mencapai target yang ditentukan.

Menurut Santrock (2010) diantara strategi yang efektif adalah menentukan subtujuan, menggunakan algoritma, dan mengandalkan heuristik. Subtujuan adalah menentukan tujuan, bagaimana sekolah dasar dapat mencapai tujuan menjadi sekolah bermutu. Melalui penentuan tujuan maka langkah dalam menyelesaikan masalah semakin jelas. Algoritma merupakan strategi yang menjamin solusi dari masalah. Melalui algoritma berbagai alternatif dapat dilakukan sesuai prosedur. Sedangkan heuristik adalah suatu strategi praktis yang mungkin dilakukan penyelesaian, tetapi tidak menjamin solusi tersebut. Menurut McGregor dkk, (dalam Santrok, 2010) melalui heuristik akan mempermudah dalam kemungkinan menyelesaikan masalah.

Strategi sangat bervariatif sesuai dengan yang diinginkan sekolah, supaya memperoleh hasil yang maksimal dan tepat sasaran maka perlu memperhatikan karakteristik strategi yang dipilih. Biasanya banyak sekali berbagai macam strategi, yang terpenting adalah setiap masalah dapat 
diselesaikan dengan satu strategi yang cocok. Melihat banyak sekali strategi maka sangat dianjurkan ketepatan dalam mengambil satu strategi yang paling baik.

Langkah yang ketiga adalah mengeksplorasi solusi. Dari berbagai alternatif penyelesaian, dipilih satu cara yang paling tepat. Kemudian sekolah mengidentifikasi secara menyeluruh untuk mengetahui karakteristik solusi tersebut. Apakah benar-benar menyelesaikan masalah yang dimaksud ataukah malah menambah masalah, karena ketidaktepatan dalam memilih solusi. Mengeksplorasi dapat berupa kegiatan mengamati, menanya, dan menjabarkan sedetail mungkin untuk memperoleh gambaran solusi yang lengkap.

Langkah yang terakhir adalah memikirkan kembali masalah dan solusi. Memikirkan kembali masalah dan solusi merupakan kegiatan untuk meneliti kembali masalah dan solusi yang benar-benar memberikan penyelesaian. Masalah ditinjau lagi dengan kalimat tanya yang sekiranya benar-benar menggambarkan masalah yang sebenarnya. Begitupula dengan solusi, diidentifikasi lagi secara detail dan menyeluruh supaya dapat gambaran bahwa solusi yang dipilih sesuai dengan konteks masalahnya. Oleh karena itu, sangat penting bagi sekolah untuk menguasai keterampilan dalam menyelesaikan masalah. Karena masalah di sekolah dasar sangat banyak sekali macam, apalagi dalam rangka mewujudkan sekolah dasar berbasis mutu. Maka tantangan dan hambatan dalam mewujudkan sekolah dasar berbasis mutu harus diselesaikan dengan cara yag tepat.

\section{KESIMPULAN DAN SARAN}

Dalam rangka mewujudkan lulusan sekolah dasar yang bermutu yaknilulusan yang mampu bersaing dengan lulusan sekolah dasar negara lain, maka diperlukan sekolah dasar berbasis mutu. Sekolah dasar yang bermutu akan menjadi pondasi awal dalam menciptakan lulusan yang bermutu, karena dengan berbagai kelebihan yang dimiliki oleh sekolah bermutu, berbagai karakteristik siswa akan dibentuk menjadi siswa yang berkualitas. Siswa akan belajar sesuai dengan keunggulan yang dimiliki oleh sekolah bermutu. Sehingga siswa yang sudah lulus dari sekolah dasar bermutu akan dapat bersaing dengan siswa lainya di seluruh dunia. Selain itu, siswa tersebut juga dapat mengaplikasikan secara langsung tentang bebagai ilmu yang diperoleh selama di sekolah ke dalam masyarakat nyata.

Sebelum mewujudkan sekolah dasar berbasis mutu, maka terlebih dahulu harus dipahami kriteria sekolah dasar bermutu. Kriteria sekolah dasar bermutu terdiri dari 5 kriteria pokok, yakni: 1) fokus pada kostumer, baik kostumer internal maupun kostumer eksternal, 2) melibatkan semua orang yang memiliki kepentingan dengan sekolah dasar sesuai dengan perannya masing-masing, 3) melakukan pengukuran terhadap semua sistem yang ada di dalam sekolah dasar, 4) memiliki komitmen yang tinggi dalam mewujudkan sekolah bermutu, 5) melakukan perbaikan secara berkelanjutan untuk menyempurnakan sistem yang sudah dibuat oleh sekolah dasar. 
Sedangkan, untuk mewujudkan sekolah dasarberbasis mutu, diperlukan langkah yang tepat supaya tujuan yang ingin dicapai sekolah dasar dapat diwujudkan dengan baik. Langkah-langkah tersebut dibagi menjadi menjadi lima, yaitu: 1. Mengorganisasikan, 2. Merencanakan, 3. Mengimplementasikan, 4. Memonitoring, dan 5. Perbaikan berkelanjutan. Untuk melaksanakan setiap tahap tersebut, diperlukan kerjasama semua pihak. Tujuan kerjasama semua pihak tersebut adalah agar semua pihak yang memiliki kepentingan dengan sekolah dasar dalam menjalankan peranya sesuai tugasnya masing-masing.

Dalam setiap pelaksanaan standar mutu di sekolah dasar pasti ditemukan berbagai masalah, maka sekolah dasar harus mampu menyelesaikan dengan cara yang tepat sesuai dengan bentuk masalahnya. Oleh karena itu, untuk menentukan penyelesaian yang tepat terhadap berbagai masalah yang dihadapi, sekolah dasar harus menguasai keterampilan menyelesaikan masalah yang baik. Hal itu dapat dilakukan dengan memahami akar masalahnya kemudian ditentukan penyelesaiannya. Untuk mencapai penyelesaian masalah yang tepat, maka semua pihak yang ada di sekolah dasar harus dilibatkan dalam mengambil keputusan. Sehingga hasil dari penyelesaian masalah dapat dterima oleh semua pihak.

\section{DAFTAR PUSTAKA}

Arcaro, Jerome S. (2007). Pendidikan Berbasis Mutu: Prinsip-prinsip Perumusan daan Tata Langkah Penerapan. Yogyakarta: Pustaka Pelajar.

Muhaimin, Suti'ah, dan Prabowo, Sugeng Listyo. (2012). Manajemen Pendidikan: Aplikasinya dalam Penyusunan rencana Pengembangan Sekolah/Madrasah. Jakarta: Prenada Media Group.

Idi, Abdullah. (2014). Pengembangan Kurikulum Teori dan Praktek. Jakarta: Raja Grafindo Persada.

Santrock, John, W. (2010). Psikologi Pendidikan. Jakarta: Kencana.

OECD. (2004a).Learning for tomorrow's world: First results from PISA 2003. Paris, France: OECD.

OECD. (2012). Equity and Quality in Education: Supporting Disanvantaged Student and Schools: OECD.

OECD (2019), PISA 2018 Results (Volume I): What Students Know and Can Do, PISA, OECD Publishing, Paris, https://doi.org/10.1787/5f07c754-en

OECD (2019), PISA 2018 Results (Volume II): Where All Students Can Succeed, PISA, OECD Publishing, Paris, https://doi.org/10.1787/b5fd1b8f-en 
OECD (2019), PISA 2018 Results (Volume III): What School Life Means for Students' Lives, PISA, OECD Publishing, Paris, https://doi.org/10.1787/acd78851-en . (2005b). PISA 2003 data analysis manual. Paris, France: OECD. . (2006c). PIRLS. Paris, France: OECD. . (2007d). PISA 2006 science competencies for tomorrow's world. Volume 1. Paris, France: OECD. . (2007e). PISA 2006. Volume 2. Paris, France: OECD.

Osaki, Kalafunja M. (2000). Quality of Education in Tanzania: A Focus on Curriculum, Standarts Accountability in Schools. University of Dar Es Salam.

UNESCO. (2006). Teachers and Educational Quality: Monitoring Global Need for 2015. Canada: Unesco Institute for Statistics.

Barret, Angeline M. Duggan, Rita Chaula. Lowe, John. Nikel, Jutta, Ukpo, Eugenia. (2006). The Concept of Quality In Education: A Review Of The 'International' Literature on The Concept of Quality In Education. United Kingdom: University of Bristol. 